\section{Iankovyi 0 ., Koshelek G., Iankovyi V.}

\title{
REALIZATION OF THE COMPLEX FORECAST OF AN ENTERPRISE'S CASH FLOWS
}

Розглянуто прогнозування змінних, які пов'язані балансовими рівностями. Визначено прочес прогнозування, який складається з чотирьох етапів. Запропоновано принщип відбору рівнянь відповідно до якості характеристик вирівнювання та за умовою дотримання балансової рівності. Доведено, що чим ближче розбаланс прогнозу до нуля, тим більше підстав вважати саме ию комбінащію функцій найкращим предиктором $i$, навпаки.

Ключові слова: грошові кошти, грошовий потік, трендова модель, предиктор, баланс змінних, якість прогнозу.

\section{Introduction}

In modern conditions, the forecasting of cash flows is closely related to strategic planning of the future development of enterprise and the implementation of financial planning. Any forecast is subjective and is not needed to determine the exact values of inflows and outflows of funds, but to determine certain benchmarks for varying the forecast indicators. It is very difficult to predict the majority of indicators with a high degree of accuracy in economics, so it is important to choose the correct methods for forecasting cash flows.

\section{The object of research and its technological audit}

The object of research is a complex forecasting of cash flows on the example of PJSC «Odeskabel», which is the largest producer of cable products in Ukraine and abroad.

There are several methods of statistical forecasting of cash flows.

1. Point forecasting on the average annual absolute growth or the average annual growth rate of cash flows. The result of this method is submitted in the form of one number. This is the simplest, but the least reliable, method of statistical forecasting. This method of forecasting is used for cases when the change in the values of the levels of cash flows is uniform or equally accelerated.

2. Extrapolation of the received trend of cash flow development based on the trend equation. The type and parameters of the trend equation are determined and the errors in the trend and forecast are estimated according to the methodology adopted in the statistics. Interval forecasting is carried out by determining two numbers. They are the upper and lower limits of the confidence interval with a predetermined probability of getting into this interval of the actual value of the cash flow. The statistical soft and the MS Excel are used to determine the trend line.

3. Forecasting of cash flows based on the regression model. This forecast concludes in the selection of factors and the evaluation of their influence on the studied indicator. For example, the sales income is affected by the sale price, sales volume, market conditions, product quality, and so on. A regression equation is obtained by statistical estimation of the degree of interaction of selected factors and the resultant characteristic. In the process of forecasting of cash flows, the planned or target values of factors are substituted into the obtained regression model. Then, the predicted value of the outcome which corresponds to these conditions is calculated.

4. Forecasting of cash flows based on elasticity coefficients. Elasticity is a relative degree of response of one value to a change of the other.

\section{The aim and objectives of research}

The aim of research is a complex forecasting of the company's cash flows. The principle of balancing of the variable cash flows of an enterprise is used for it.

To achieve this goal, the following tasks are set:

1. To consider statistical methods of forecasting of cash flows.

2. To study the principle of the balance of variable cash flows of the enterprise.

3. To adapt the principle of the balance of variable cash flows to the activities of the PJSC «Odeskabel».

\section{Research of existing solutions of the problem}

A lot of attention has been paid to the development of a system of forecasting and financial planning of cash flows in modern conditions in scientific economic literature in recent years. This issue is being studied both by foreign scientists and economists, and by domestic ones.

For example, the cash flow forecast is considered in research as the most important apparatus for managing cash, which helps to avoid their shortage [1], it is emphasized that detailed forecasts of cash flows can be reasonably made only when measuring short-term liquidity [2], planning and forecasting of cash flows is defined as one of the stages of their management [3].

In some works attention is drawn to the planning of the volume and structure of the company's cash flows [4], it is proved that formally the prediction procedures are developed in the methods of analytical processing of the 
dynamics series. The method «from what has been achieved» is the most often used in forecasting [5]. In [6] it is proposed to use the forecasting of cash flow for valuation, the cost of the investment capital of an enterprise within the income method, and [7] considers the forecasting of the financial condition of an enterprise using a trend analysis of cash flows. In [8] it is provided company's evaluation, which is carried through by different methods using cash flows. Based on the above, it can be noted that in the reviewed publications the issue of determining of methods for forecasting cash flows has not been fully studied yet.

\section{Methods of research}

Statistical methods, in particular, extrapolation methods, trend models, the method of group accounting of arguments, etc. were used to solve the problems.

\section{Research results}

Statistical methods, in particular analysis and analytical alignment of the dynamics series, their extrapolation and calculation of confidence intervals, are the main methods used for formation of long-term forecasts. In this case, the most important role is played by the correct choice of the form of trends, which are adequately describing the processes under study. There are a number of practical approaches that make it possible to solve this problem relatively successfully and to obtain satisfactory results of extrapolation at present. These are a qualitative socioeconomic analysis of the researching phenomenon, encompassing its internal logic and formation mechanism, visual researching of the dynamics graphs, the method of coherent differences, the method of growth characteristics etc.

All of them are quite suitable for forecasting of isolated indicators. However, the situation changes fundamentally when a simultaneous prediction of several interrelated variables is carried out, such as the volume of gross, net output and material costs; birth rate, mortality and natural population growth; return of foreign trade, exports, imports, etc. [9]. In this case, traditional methods of choosing the form of trends do not exclude the possibility of obtaining an erroneous, «divergent» forecast, which violates the fundamental qualitative relations and interrelations.

In order to avoid this danger, in the complex statistical forecasting of interdependent socio-economic indicators, we suggest choosing the form of trends using the principle of the balance of variables. It can be formulated as follows: the final conclusion on the acceptability of certain forms of curves is determined by the degree of compliance of the predicted values to the balance ratio, which is valid for the period of prehistory.

The rationality of such an approach is unquestionable, because we know about the future precisely that it retains the same interrelationships between the features that took place in the past and in the present. Therefore, the criteria based on the principle of the balance of variables should occupy a priority position throughout the hierarchy of criteria for selecting patterns of trends.

Let us illustrate the proposed principle with the following example. Let it be necessary to obtain a complex statistical forecast of variables between which there is a next relation:

$$
Y_{1 t}+Y_{2 t}+\ldots+Y_{m-1 t}=Y_{m t},
$$

where $m$ is the number of interrelated variables.

When solving forecasting problems in this area, the extrapolation methods play a leading role. They are based on the premise of the inertia of development of dynamic probability systems. Among these methods an important place is occupied by trend models describing the variation of the studied variables as a function of the time $t-$ generalizing argument, which accumulates the cumulative effect of a number of main factors. Output series of dynamics $Y_{i t}$ are represented as sums of two components that are not observed:

$$
Y_{i}=f_{i}(t)+\varepsilon_{i},
$$

where $f_{i}(t)$ is the trend equation; $\varepsilon_{i}$ is the random component.

Trends (2) characterize the main regularities of the change of the parameters of the socio-economic system in time, and the accuracy and reliability of forecasting largely depend on the correctness of the choice of the trend form, i. e. of the form of the analytic function $f_{I}(t)$. The most accurate and reliable results of forecasting are obtained in that case if a true mechanism of development of the process in time is discovered. So the problem of the quality of forecasts obtained by trend models is reduced to searching for internal patterns of growth, development, and dynamics.

There are a number of ways which make it is possible to solve this problem in conditions of isolated forecasting of individual variables more or less successfully. First of all, this is a qualitative theoretical analysis of the studied process which allows us to disclose its internal logic and the formation mechanism in interrelation with other variables. However, the possibilities of such an analysis, as a rule, are very limited. At best, it shows the characteristics of the dynamics in general terms, which is often not enough to justify the choice of the trend form. Therefore, qualitative analysis, being the informative basis of forecasting, is supplemented by the study of empirical data.

The first way is the simplest one called visual. It is the choice of the trend form due to the visual study of a series of dynamics. But at the same time, the risk of a subjective decision is very high. Different researchers can give quite convincing arguments in favor of various forms of the curve using the same graph. In addition, the result of choice is strongly influenced by the scale of the graphic image.

The second way, which is usually recommended in the literature, is the method of coherent differences. The first, second, and other differences in the levels of the series are calculated in accordance to it. The calculation continues until the differences are approximately equal. The order of differences is taken as the degree of the approximating polynomial.

There are other methods of determining the trend form based on the analysis of empirical data, for example, the method of growth characteristics [10]. All of them have certain advantages and disadvantages and often give quite satisfactory results in the analysis and prediction of the series of dynamics, which are considered in isolation. However, the situation changes radically when a simultaneous prediction of several interrelated variables of the type (1) 
is carried out. In this case, the above methods of choosing the form of trends do not exclude the possibility of obtaining a false forecast, which violates the fundamental quantitative relationships. However deep the methods of extrapolating of individual isolated series of dynamics can be developed, they cannot insure against obtaining the so-called «fan» of forecasts, which is distinguished by the absurdity of the predicted values of the studied variables in terms of their internal dependence.

In order to avoid these shortcomings in medium- and long-term forecasting of variables between which there are objective interrelations, we propose to supplement the traditional methods of choosing trend forms with the principle of the balance of variables. It can be summarized as follows: the final conclusion about the acceptability of certain analytical functions for describing the dynamics of interrelated indicators (i. e. the choice of the predictor) is determined by the degree of compliance of the predicted values of the variables to the balance ratio resulting from formula (1).

This principle realizes sort of the impossible: it provides a foothold in the future. Indeed, what do we know about the future? Only follows: the balance ratio (1) will be implemented in the same way as it is being performed now, or was done in the past! Therefore, it is quite logical to choose as a predictor such a combination of analytical functions of the studied variables that will ensure the most balanced value of the forecast data.

The principle and the based on it criterion of the balance of variables was developed first in the theory of heuristic self-organization when solving the problems of technical cybernetics. It is universal in nature and can be used in studying of any systems. Self-organization approaches are characterized by the effective use of a minimum of a priori information about the studied object when it is considered as «black box». Therefore, the principle of the balance of variables in combination with traditional methods of choosing the form of trends is extremely productive in predicting of parameters of complex probability systems [9].

In this case the forecasting process consists of four main stages [11]:

1. Selection of possible candidate functions, which most accurately describe the studied series of dynamics.

The traditional methods of statistical modeling are widely used at this stage. They are a qualitative theoretical analysis, visual study of graphs, calculation of coherent differences, growth characteristics and other parameters, including the criteria of mathematical statistics. As a result, several basic, most adequate to the process of cash flows of an enterprise, support functions, the number of which can be quite large, are selected at the first stage. The parameters of each of the selected functions are determined by the method of least squares, extrapolation is performed, and the predicted values of the indicators are calculated for a given lead-time period.

The series of dynamics of each indicator taken during the period of prehistory can be represented with trend models of the type (2) [11]. It is important to pay attention to the choice of the optimal length of the period of prehistory. The fact is that the dynamics of the company's cash flows is often a subject of rather strong fluctuations which are caused, in particular, by certain random factors [12]. That is why, it is important to determine correctly the length of the prehistory period and cut off the «old» data.

2. Sequential search of a limited number of combinations of basic functions which are highlighted in the previous stage. As an assessment of each combination is the degree of compliance with the original balance ratio for all points of the lead-time period. The best combination corresponds to the minimum value of the criterion for the balance of variables [9]:

$$
B_{j}=\frac{\sum_{t 1}^{t 2}\left(Y_{m t}-Y_{1 t}-\ldots-Y_{m-1 t}\right)^{2}}{\sum_{t 1}^{t 2} Y_{m t}^{2}} \rightarrow \min ,
$$

where $t_{1}-t_{2}$ - the lead-time period; $B_{j}$ - the total relative magnitude of the forecast imbalance for all points of the lead-time period.

There are more reasons to consider the combination of functions as the best predictor when the imbalance of the forecast $B_{j}$ is closer to zero and vice versa. If no suitable function describing the dynamics of the interrelated variables sufficiently accurately is found out in the first stage, then the set of values of $B_{j}$, as the trend is sorted, necessarily passes through the global minimum. The total number of combinations of candidate functions $j$ (predictors) that are checked in the second stage is determined by the value:

$$
j=a \times b \times \ldots . . \times n,
$$

where $a, b, \ldots, n$ is the number of candidate functions selected in the first stage to describe each variable.

For example, if 5 initial candidate functions are selected for three variables in the first stage of the forecast, then $j=5 \times 5 \times 5=125$.

Obviously, sorting out such a number of combinations and calculating for each $B_{j}$ value manually is a very laborious task. Modern high-speed personal computers that allow to fully automate the second stage come to helping enumeration of options and calculation of the values of the criterion of the balance of variables. It remains only to specify the form of the function in the numerator (3), which follows from the essence of the studied interrelated variables. PC chooses by itself the type of predictor. It is important to set correctly the search environment for the optimal combination only.

3. Selection of the optimal length of the prehistory period. It is known that the dynamics of socio-economic indicators are prone to changes caused by subjective political-economic and other factors which are reflected in the random component $\varepsilon_{i}$. It is important to determine correctly the length of the period of prehistory, take into account the current trends, abstracting from too early and «outdated» observations. The predicted value should not contradict to the logic of modern development of the studied processes.

4. Determination of point and interval values of the forecast. This stage completes the process of integrated forecasting of interrelated socio-economic indicators. It is the usual extrapolation of the obtained trends and the calculation of confidence intervals for forecasts.

The depth of the minimum of the variable balance criterion reflects the success of the forecasting process. 
The close to zero values of $B_{j}$ indicates the existence of an optimal combination of functions used for forecasting and signals about the finding of the optimal predictor. In opposite, high values of imbalance indicate errors in the first stage of selection, i. e. the omission of some important candidate functions, which describe the dynamics of the studied variables well. Therefore, the first stage is the most important in the whole process of forecasting. Like the grind mill, which does not give quality flour when using poor grain material, the variable balance criterion (3) cannot determine the best predictor if the first stage did not include the most appropriate functions to the studied indicators. Consequently, the success of forecasting largely depends on the professional knowledge, experience and skills of the researcher [12].

At the same time, the second stage, which makes it possible to evaluate each variant of the forecast with the most appropriate (from the point of view of the set goals) criterion, allows to eliminate the uncertainty that often arises in the first stage. In this sense, both stages play an important role in the process of determining the optimal combination of trend forms. Therefore, they should be used in indissoluble unity, as a necessary and sufficient condition for successful forecasting of interrelated socio-economic indicators.

As for randomness in choosing the optimal combination of trend forms, it is practically excluded by the law of impossibility of an unlikely event. Indeed, the probability of a random zero imbalance of the predicted values of the variables even at one point in the lead-out period coincides with the probability of a certain trend arrangement, some of which incorrectly describe the studied series of dynamics.

In our opinion, this method can be successfully used to predict cash flows of an industrial enterprise. Let's consider the contents of the specified stages on example of forecasting of inflow, outflow of cash and a net cash flow of PJSC «Odeskabel» for 2004-2016. The initial data, which form the period of prehistory, are taken from the website of the Ukrainian Stock Market Infrastructure Development Agency [13]

As initial support functions for trend models of inflow and outflow of funds, we used a linear function, parabolas of the second and third degree. And for the trend models of net cash flow the parabolas of the second and third degree were applied. Three groups of models, including 18 equations, were obtained as a result of calculations on PC using Microsoft Office Excel software. The analysis of the coefficients of determination made it possible to identify 8 trends that most adequately describe the studied features.

It is logical to apply the traditional approach, according to which the most accurate trends should be chosen as the forecast model in the conditions of isolated forecasting of economic indicators. These are a parabola of the third degree $\left(R^{2}=0.9294\right)$ for the inflow, a parabola of the third degree $\left(R^{2}=0.9294\right)$ for the outflow and also a parabola of the third degree $\left(R^{2}=0.9294\right)$ for net cash flow. Therefore, at first blush, the best combination of trends is $(3-3-2)$.

But taking into account the set task, which is complex forecasting of inflow and outflow indicators and net cash flow, we will not rush to conclusions. There are only $18(3 \times 3 \times 2)$ predictors and, accordingly, 18 diffe- rent options for estimating of future values of interrelated economic indicators that differ at least by the value of one characteristic. It is not excluded that among these variants there will be combinations, the accuracy of which by the criterion of the balance of variables will be higher than that of the trivial solution $(3-3-2)$.

Let us pass to the second stage of prediction, which is a direct search of all 18 combinations of the studied functions by $B_{j}$. The search of variants and the calculation of the values of the criterion for the balance of variables for two-year forecasted data were carried out on PC. We give only the main results of calculations which contain a practical interest (Table 1).

Table 1

values of the criterion of the balance of variables in the initial series of dynamics of the PJSC «Ddeskabel» for 2004-2016

\begin{tabular}{l|l|l|l|l|l|l|l|l|}
$2-1-1$ & $1-3-1$ & $2-3-1$ & $1-2-2$ & $2-2-2$ & $1-3-3$ & $1-1-3$ & $2-1-3$ \\
\hline
\end{tabular}

\begin{tabular}{|l|l|l|l|l|l|l|l|l|}
\hline & & & & & & & & \\
\hline
\end{tabular}

calculated by the authors.

It can be seen from the spreadsheet that the predictor 1-2-2 $\left(B_{1-2-2}=0.0881\right)$ provides the most balanced forecast when the series of dynamics of all three studied indicators are described by a parabola of the second degree. The next one is the predictor $1-3-3 \quad\left(B_{1-3-3}=0.1087\right)$. We cannot fail to note an obvious relationship between the coefficients of the equations:

$$
\begin{aligned}
& Y_{1 t}=11708 x^{2}-10892 x+35188 \\
& Y_{2 t}=11322 x^{2}-7067.7 x+28618 \\
& Y_{3 t}=385.37 x^{2}-3808.8 x+6464.4
\end{aligned}
$$

In other words, the trend coefficients that describe the dynamics of net cash flow are approximately equal to the difference in the corresponding trend coefficients describing the change in the cash inflows and outflows. Indeed, the discrepancies are $\Delta a_{0}=0.63 ; \Delta a_{1}=15.5 ; \Delta a_{2}=105.6$. That is why we have such a high balance of aligned values of variables and for points of the lead-time period.

\section{SWOT analysis of research results}

Strengths. The strength of applying of the principle of the balance of variables based on the criterion $B_{j}$ is that it allows to provide complex forecasting of interrelated indicators and to choose the best variant of a combination of trend forms (the best predictor).

Weaknesses. The weakness of this method is a certain subjectivity of the researcher, who performs selection of all possible candidate functions for predicting the studied indicators at the first stage.

Opportunities. Opportunities lie in the potential maximum use of empirical information of short series of dynamics, obtaining the most accurate and objectively grounded estimates of future values of the levels of economic indicators

Threats. The threats are the ability to skip certain important approximating function at the first stage of the method, as well as the uncertainty in the political and 
financial and economic environment that causes strong volatility of the forecast economic indicators and reduces the accuracy of the carried out study.

\section{Conclusions}

1. The main methods of forecasting are statistical methods, in particular analysis and analytical alignment of the dynamics series. It is important to choose the forms of trends that describe the studied economic phenomena correctly. These approaches are used for isolated forecasting of socio-economic indicators.

2. It is proposed to choose the trend forms using the variable balance principle in complex statistical forecasting of cash flows. The process of forecasting of cash flows consists of four main stages.

3. The complex forecasting of indicators of inflow, outflow of cash and a net cash flow using the principle of balance of variables based on the initial data of the PJSC «Odeskabel» for 2004-2016 is carried out. This made it possible to choose the best variant of combining of trend forms in complex forecasting. This approach provides the most accurate and objectively grounded estimate of future values of the levels of the studied indicators.

\section{References}

1. Tennent, J. Guide to Cash Management: How to Avoid a Business Credit Crunch [Text] / J. Tennent. - Economist Books, 2012. - 224 p

2. Bernstein, L. Analysis of Financial Statements [Text] / L. Bernstein, J. Wild. - Ed. 5. - McGraw-Hill Education, 1999. - 529 p.

3. Poddierohin, A. M. Efektyvnist upravlinnia hroshovymy potokamy pidpryiemstva [Text] / A. M. Poddierohin, Ya. I. Nevmerzhytskyi // Finansy Ukrainy. - 2007. - № 10. - P. 119-127.

4. Blank, I. A. Upravlenie denezhnymi potokami [Text] / I. A. Blank. Kyiv: Nika-Tsentr, Elga, 2002. - 736 p.

5. Kovaliov, V. V. Upravlenie denezhnymi potokami, pribyl'iu i rentabel'nost'iu [Text] / V. V. Kovaliov. - Moscow: Prospekt, 2015. - 338 p.

6. Perevozchikov, A. G. Prognozirovanie denezhnogo potoka na osnove otraslevyh pokazatelei iz sbornikov finstat [Text] / A. G. Perevozchikov // Audit i finansovyi analiz. - 2006. № 3. - P. 142-147.
7. Salyla, S. Ya. Trendovyi analiz hroshovykh potokiv yak zasib informatsiinoho zabezpechennia protsesu biudzhetuvannia v upravlinskomu obliku [Text] / S. Ya. Salyha, N. O. Zavadska // Biznes Inform. - 2012. - № 6. - P. 178-187.

8. Bertoneche, M. Financial Performance [Text] / M. Bertoneche, R. Knight. - Elsevier, 2001. - 208 p. doi:10.1016 b978-075064011-4.50000-4

9. Iankovyi, O. Prognozirovanie sotsial'no-ekonomicheskih pokazatelei na osnove printsipa balansa peremennyh [Text] O. Iankovyi // Ekonomika i matematicheskie metody. - 1993. Vol. 29, № 1. - P. 108-118.

10. Chetyrkin, E. M. Statisticheskie metody prognozirovaniia [Text] E. M. Chetyrkin. - Moscow: Statistika, 1977. - 200 p.

11. Iankovyi, O. Latentni oznaky v ekonomitsi [Text]: Monograph / O. Iankovyi. - Odesa: Atlant, 2015. - 168 p.

12. Ivahnenko, A. G. Samoorganizatsiia prognoziruiushchih modelei [Text] / A. G. Ivahnenko, I. A. Miuller. - Kyiv: Tehnika, 1985. - 223 p.

13. Stock market infrastructure development agency of Ukraine (SMIDA) [Electronic resource]. - Available at: \www/ URL: https://smida.gov.ua/

\section{СОСТАВЛЕНИЕ КОМПЛЕКСНОГО ПРОГНОЗА ДЕНЕЖНЫХ ПОТОКОВ ПРЕДПРИЯТИЯ}

Рассмотрены прогнозирования переменных, связанных балансовыми равенствами. Определен процесс прогнозирования состоящий из четырех этапов. Предложен принцип отбора уравнений в соответствии с качеством характеристик выравнивания и при условии соблюдения балансового равенства. Доказано, что чем ближе разбаланс прогноза до нуля, тем больше оснований считать именно эту комбинацию функций лучшим предиктором и, наоборот.

ключевые слова: денежные средства, денежный поток, трендовая модель, предиктор, баланс переменных, качество прогноза.

Iankozyi Oleksandr, Doctor of Economic Sciences, Professor, Department of Economic of Enterprises and Entrepreneurship Organization, Odessa National Economic University, Ukraine, e-mail: yankovoy_a@ukr.net, ORCID: http://orcid.org/0000-0003-2413-855X

Koshelek Halina, PhD, Associate Professor, Department of Economic of Enterprises and Entrepreneurship Organization, Odessa National Economic University, Ukraine, e-mail: galas2811@gmail.com, ORCID: http://orcid.org/0000-0003-0331-0592

Iankovyi Volodymyr, PhD, Associate Professor, Department of Economy and Planning of Business, Odessa National Economic Univer sity, Ukraine, e-mail: vladimir ya@ukr.net,ORCID: http://orcid.org/ 0000-0001-7005-5291 